\title{
Proteomics of Human Teeth and Saliva
}

\author{
M. JÁGR ${ }^{1}$, A. ECKHARDT ${ }^{1}$, S. PATARIDIS ${ }^{1}$, Z. BROUKAL ${ }^{2}$, J. DUŠKOVÁ ${ }^{2}$, I. MIKŠÍK ${ }^{1}$ \\ ${ }^{1}$ Department of Analysis of Biologically Important Compounds, Institute of Physiology Academy \\ of Sciences of the Czech Republic, Prague, Czech Republic, ${ }^{2}$ Institute of Clinical and Experimental \\ Dental Medicine, First Faculty of Medicine, Charles University and General University Hospital \\ in Prague, Prague, Czech Republic
}

Received November 20, 2013

Accepted December 4, 2013

\begin{abstract}
Summary
Teeth have been a focus of interest for many centuries - due to medical problems with them. They are the hardest part of the human body and are composed of three mineralized parts enamel, dentin and cementum, together with the soft pulp. However, saliva also has a significant impact on tooth quality. Proteomic research of human teeth is now accelerating, and it includes all parts of the tooth. Some methodological problems still need to be overcome in this research field - mainly connected with calcified tissues. This review will provide an overview of the current state of research with focus on the individual parts of the tooth and pellicle layer as well as saliva. These proteomic results can help not only stomatology in terms of early diagnosis, identifying risk factors, and systematic control.
\end{abstract}

\section{Key words}

Proteomics • Tooth • Dentin • Enamel • Pulp

\section{Corresponding author}

I. Mikšík, Institute of Physiology, Academy of Sciences of the Czech Republic, v.v.i., Vídeňská 1083, 14220 Prague 4, Czech Republic. Fax: +420 296442558. E-mail: miksik@biomed.cas.cz

\section{Introduction}

The proteomics of the different types of human cells, organs, tissues and fluids has been a major research topic in life sciences all over the world for the last few decades and useful basic data for a variety of targeted tissues are still greatly needed (Rabilloud et al. 2010).

The human tooth is the hardest part of the human body, with a specific construction and constitution. It is composed of three distinct highly mineralized and hard tissues (enamel, dentine, and cementum). The soft tooth tissue is the pulp, with blood vessels and neural fibers (Fig. 1). The tooth is surrounded by connective tissue called the periodontal ligament, which attach and suspend the tooth inside the socket of the alveolar bone.

Enamel is the most mineralized part of the tooth and is harder than iron, providing the exposed crown with durable cutting and grinding surfaces. Inorganic material makes up about $97 \%$ of mature enamel. The rest is formed of proteins and other components, such as water.

Dentin forms the main structure of the tooth and has some flexibility, being compositionally similar to bone. It is a highly mineralized tissue that forms the bulk of the tooth, serving as a protective covering for the pulp as well as a support for the overlying enamel and cementum. Teeth also contain predentin, an unmineralized portion. Predentin is located between the odontoblasts and the mineralized dentin and remains throughout the life span of the tooth. The dentinal tubules, which run between the pulp and dentin, are the area where odontoblasts operate. On a weight basis, mature dentin is approximately $70 \%$ mineral, $20 \%$ organic matrix (e.g. glycoproteins, phospholipids), and $10 \%$ water (Linde 1989).

Cementum, produced by specialized cells called cementoblasts, is a mineralized tissue covering the dental root and anchors the fibrous periodontal ligament that links the tooth to the alveolar bone (Hubbard and Kon 2002). Dental cementum is often described as a bone-like 
avascular and non-innervated mineralized tissue with a specific morphology and matrix composition.

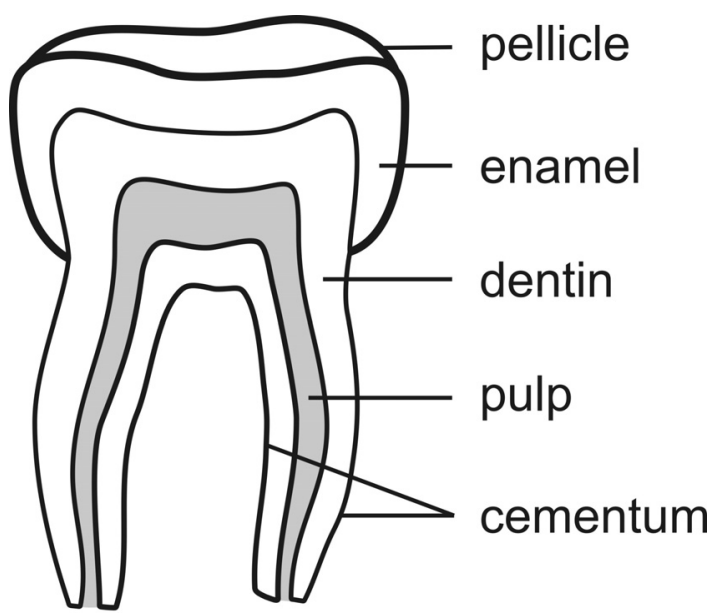

Fig. 1. Detailed structure of human tooth.

Dental pulp is the main inner and soft tissue of teeth. It is located in the coronal pulp chamber and root canals. Dental pulp tissue contains connective tissue, mesenchymal cells, blood vessels, and lymphatics. It is innervated by neural fibers which forms a complex system of innervation. In human tooth, the odontoblastic layer of the coronal dental pulp is associated with an extensive sensory network involved in the transmission of sensory stimuli from the dentin-pulp complex and in the cellular defense against pathogens (Couve et al. 2013).

Whole saliva is a fluid produced by the major and minor salivary glands. It is mainly composed of water, other components including proteins, peptides, hormones, lipids, sugars and ions (Vitorino et al. 2012). Beside the secretions from salivary glands, oral mucosa, periodontium as well as oral microflora also contribute to the final content of whole saliva. This enables saliva to be used in the diagnosis of oral and systemic diseases (Al-Tarawneh et al. 2011).

The acquired enamel pellicle is a thin (ca. $0.5-1 \mu \mathrm{m}$ ) layer that is formed on the enamel surface of teeth by selective adsorption of saliva compounds. It is composed mainly of mucins, glycoproteins and proteins (Hannig et al. 2005). The acquired pellicle plays an important role in the crystal growth homeostasis of the teeth, and in the physico-chemical defence of tooth surfaces (Fábián et al. 2008).

Current research has shown that over $90 \%$ of all adults experience dental caries, only $10 \%$ of late adolescents and young adults in the United States are caries-free or caries-resistant (García-Godoy and Hicks 2008). Dental caries continues throughout adulthood, with more than $95 \%$ of adults experiencing caries on enamel and root surfaces, and it leads to complete loss of teeth in $25 \%$ of people. Caries prevalence and severity have increased over the past decade in young children, particularly in their primary dentition. Dental caries is a multifactorial disease that includes the participation of cariogenic bacteria, salivary components (proteins, enzymes) and dietary sources of fermentable carbohydrates (García-Godoy and Hicks 2008). The overall roles of all these effects in the development of dental caries still remain unclear and are worthy of further investigation.

Only a small part of the world population is well protected against the prevalence of dental caries (http://www.who.int/oral_health/disease_burden/global/en; 30.10.2013). This anti-caries resistance can be caused by the overall immune system, composition of saliva, or nourishment, specific dental care and by many other causes. Last but not least, the resistance could be caused by the presence of specific protein antibacterial agents inside the teeth tissues (pulp, dentin or enamel). In fact, it still remains unclear and explaining these facts could be very important and make a significant contribution to planning and evaluating future preventive activities and oral health promotion.

A proteomic investigation of hard dental tissues (enamel, dentin, and cementum) must overcome severe methodological problems. One of them is the need to remove the excess of calcium and other minerals from the calcified tissues. Calcium chelators or acids are usually used (Porto et al. 2006). The second problem lies in the poor solubility and low abundance of many matrix proteins in dental tissues (especially in the case of enamel and dentin proteins), resulting in a very low yield of proteins during tissue processing. A further difficulty is the substantial protein heterogenity associated with alternative splicing and a variety of post-translational modifications. It must also be taken into consideration that investigations of tooth development were performed extensively on rat and mouse teeth, because these samples are readily available. On the other hand, animal teeth exhibit many similarities to human teeth (Hubbard and Kon 2002). Proteomic tools can help dentistry in the identification of risk factors, early diagnosis, prevention, and systematic control that will promote the evolution of treatment in all dentistry specialities (Rezende et al. 2013). 
The aim of this paper is to review current state of the art in the proteomic field of human teeth and saliva, and to outline some connected medicinal aspects.

\section{Proteomics of enamel}

The enamel is the external part of the tooth, which functions as a grinding surface. Enamel is produced entirely before the eruption of the tooth, by specialized secretory cells called ameloblasts (Hubbard and Kon 2002). Two principal stages of enamel formation (secretion and maturation) are recognized. Enamel is first formed as a soft, protein-rich extracellular matrix, which is essential for enamel formation. The secretory-stage enamel of developing teeth contains $>30 \%$ protein. During enamel formation and maturation, the matrix is removed almost completely by enzymatic degradation by proteases, resulting in a hardening of the enamel and extensive deposition of calcium-based minerals. The final mineralized state of mature enamel is critical for resisting mechanical abrasion and chemical (dietary or bacterial) attack (McKee et al. 2013).

The structure of mature enamel is composed of micro-scale rods separated by an inter-rod material, each of which is made of staggered hydroxyapatite nanocolumns embedded in a proteinous matrix (He and Swain 2008). The inorganic composition of mature enamel was studied using various analytical methods such as instrumental neutron activation analysis, inductively-coupled plasma mass spectrometry, thermogravimetry and differential thermal analysis, and $\mathrm{X}$-ray diffraction analysis. It is not surprising that the three main elements in mature enamel are reported to be $\mathrm{Ca}$ (comprising $\sim 35 \%$ of the mass), $\mathrm{P}(\sim 15 \%)$ and $\mathrm{O}(\sim 40 \%)$. The other significant elements in mature enamel were identified to be $\mathrm{C}, \mathrm{H}, \mathrm{Na}, \mathrm{Cl}, \mathrm{N}, \mathrm{Mg}$, and $\mathrm{Zn}$ (Zenóbio et al. 2011). The elemental composition varied within certain ranges depending on the analytical method chosen.

More recently, a thin protein-containing enamel matrix layer which bridges the dentine-enamel junction of adult human teeth was identified. This novel layer is cca $100-400 \mu \mathrm{m}$ thick and is relatively rich in proteins. It was hypothesized that this protein-containing matrix layer could provide an important biomechanical linkage between the enamel and the dentine of adult teeth (Dusevich et al. 2012).

The principal structural protein for forming enamel is amelogenin. The other significant proteins in enamel are reported to be ameloblastin, enamelin and tuftelin (Hubbard and Kon 2002). Amelogenin is the predominant protein in the developing enamel extracellular matrix. The hydrophilic carboxyl-terminal of amelogenin binds hydroxyapatite as demonstrated both in vitro and in vivo. This indicates that the amelogenin (through the carboxyl-terminal region) regulates the initiation and growth of hydroxyapatite crystals during the mineralization of enamel (Shaw et al. 2004). In addition, amelogenin appears to aid in the development of cementum by directing cells that form cementum to the root surface of teeth.

Ameloblastin was originally believed to be an enamel-specific extracellular matrix glycoprotein secreted by ameloblasts. Recently, ameloblastin expression was also detected in developing mesenchymal dental hard tissues, in trauma-induced reparative dentin, and during early craniofacial bone formation (Vymětal et al. 2008). Biochemically it is classified as an intrinsically disordered protein. Its physiological role remains largely unknown; however, the question of ameloblastin function will be undoubtedly connected to its structural properties and its potential for protein-protein and protein-cell interactions. The function of ameloblastin is believed to lie in controlling the elongation of enamel crystals and generally directing enamel mineralization during tooth development (Wald et al. 2011).

Enamelin is a protein found in developing tooth enamel. Together with ameloblastin, it is one of the two most abundant non-amelogenin enamel proteins. Enamelin strongly binds to hydroxyapatite, but the mechanism of its action is not clear. The discovery of mutations in the enamelin gene in amelogenesis imperfecta kindreds proved that enamelin is critical for proper dental enamel formation ( $\mathrm{Hu}$ and Yamakoshi 2003, Hu et al. 2007).

Tuftelin is an acidic phosphorylated glycoprotein found in tooth enamel. This protein is formed for a short time during amelogenesis. The function of tuftelin remains unknown, but it is proposed that it acts as a nucleator for hydroxyapatite crystal formation and thus promoting the start of the mineralization process in enamel during tooth development. This prediction is made based on its anionic character, its localization at the dentine-enamel junction and its expression in ameloblast cells just prior to amelogenin. In addition, it is also expressed in many non-mineralizing tissues (Paine and Snead 2005).

A higher protein content was detected in 
pathologically or physically affected enamel inducing enamel hypomineralization. The enamel defects are clearly visible as a demarcated opaque, yellow or brown discolouration. These changes are accompanied by an 8- to 21-fold higher protein content compared to sound enamel. Elevated levels of serum albumin and antitrypsin and the presence of antithrombin was demonstrated. Serum albumin may inhibit apatite crystal growth (Farah et al. 2010).

The right production of proteases during enamel maturation is necessary for proper tooth development and the production of a hard as well as chemically and mechanically resistant enamel layer. Two proteases are secreted into the enamel matrix of developing teeth. The early protease is enamelysin (matrix metalloproteinase 20) and the late protease is kallikrein 4. Mutations in these two proteases cause autosomal recessive amelogenesis imperfecta, a condition featuring soft, porous enamel containing residual protein $(\mathrm{Lu}$ et al. 2008). The importance of the extracellular matrix protein can be illustrated by the dramatic changes in dental phenotypes observed in the targeted knockouts of enamel matrix genes (amelogenin, ameloblastin, matrix metalloproteinase 20, dentin sialophosphoprotein) encoding the corresponding proteins in mice ( $\mathrm{Hu}$ et al. 2005).

\section{Proteomics of dentin}

Dentin is the intermediate part of the tooth, located between the enamel and the pulp. It is less mineralized and more compliant than the enamel, functioning as a bumper for the mechanical loads applied to the tooth. Dentin includes micron-size hollow tubules surrounded by a thick layer of hyper-mineralized peritubular dentin, embedded in a low-mineralized intertubular dentin matrix. The tubules originate from the pulp and cross the dentin all the way to the enamel (Bar-On and Wagner 2013).

Unlike enamel, dentin retains a lifelong association with odontoblasts - the key cells responsible for dentin formation and maintenance. During tooth development, the odontoblasts actively secrete the primary dentine. Odontoblasts have long membrane processes that extend into the dentin, rendering the teeth sensitive to physical stimuli such as cold or hot drinks and dentist's drills. Odontoblasts communicate with pulp nerves. They play a role in defensive mechanisms and the stimulation of inflammatory responses against pathogen invasion through dentinal tubules (Couve et al. 2013). Intercellular junction complexes between odontoblasts create a pre-dentin-odontoblast barrier that constitutes the first biological line of defense against pathogens and injury, such as dental caries. They also provide a capacity for tissue repair after the removal of decayed dentin.

The formation and biomineralization of dentin is a complex and dynamic process, involving the formation of an organic network in which mineral crystals are deposited. During dentinogenesis, odontoblasts produce and secrete the organic components (proteins), which play a central role in dentin extracellular matrix organization and the regulation of mineralization (Petersson et al. 2003). As part of this process, secreted extracellular matrix proteins are sometimes modified or cleaved by enzymes and then organized into macromolecular assemblies, which are then structured into a mature fibrillar matrix ready for mineral deposition (McKee et al. 2013). The proteins can either act as nucleators in the extracellular matrix or prevent mineral formation in unwanted sites, by producing enzymes that modify the functions of these proteins, and by regulating ion transport (Boskey 2003). These remarkable tissueconstruction events are orchestrated by odontoblasts, with each being associated with a thin layer of unmineralized matrix that subsequently mineralizes at the "mineralization front" to form the completed tissue. During maturation of the teeth, additional mineralization and mineral changes occur slowly over time, along with changes in the organic phase of the extracellular matrix (McKee et al. 2013).

It had long been believed that dentine is a relatively inert tissue with no significant extracellular matrix turnover. But that now seems to be far from the truth and some recent findings show that dentin is in fact a surprisingly metabolically active tissue (Smith et al. 2012).

The most common tooth disease is dental caries (over $90 \%$ of all adults suffer from this disease). Hereditary dentin disorders are divided into 5 types: three types of dentinogenesis imperfecta, and two types of dentin dysplasia (Hart and Hart 2007). They are characterized by inherited dentin defects which not only affect collagen, but also cause other protein disorders (Butler et al. 2003, Paine et al. 2005, Barron et al. 2008).

It has recently been proposed that the structure and composition of dentine may be more heterogeneous than was previously thought (Smith et al. 2012). Some of the quantitatively minor components in the dentine and 
dentine matrix, such as growth factors, may have potent bioactive properties. There is therefore a strong need to give greater consideration to these minor but important molecular components in dentin and the dentin bioactive matrix. This has enabled many researchers, including ourselves, to begin to investigate how the mechanisms of dentinogenesis influence tissue structure and how the protein components of dentin might be used in novel therapeutic approaches.

To date, the organic matrix of dentin has been reported to contain a predominantly collagenous matrix ca 85 to $90 \%$ of the total protein (Linde 1989). In humans, there are at least 27 known types of collagen, expressed from 42 different collagen genes (Myllyharju and Kivirikko 2004). Collagen type I is the major collagenous protein in the dentin matrix, which also contains lesser amounts of type III, V, VI, XI, and XII collagens (De Coster et al. 2007, Park et al. 2009). The fibrils of collagen provide a three-dimensional scaffold for the deposition of apatite crystals (Marshall et al. 1997).

The presence of collagen in dentin closely correlates with the presence of tissue matrix metalloproteinase 2, matrix metalloproteinase 9, and matrix metalloproteinase 20 (Yamakoshi et al. 2006, Mazzoni et al. 2009). Fibronectin has also been found in association with collagen fibrils in the predentin (Park et al. 2009).

The major noncollagenous protein in human dentin is dentin sialophosphoprotein (DSPP). It is critical for proper dentin mineralization, because genetic defects in dentin sialophosphoprotein cause dentin dysplasia type II, and dentinogenesis imperfecta types II and III (Lee et al. 2011a, 2013a). During tooth formation, DSPP is expressed by odontoblasts and pre-ameloblasts, and its translation products accumulate in the dentin matrix. Dentin sialophosphoprotein is rapidly cleaved into three products: dentin sialoprotein, dentin glycoprotein, and dentin phosphoprotein (Qin et al. 2003, Tsuchiya et al. 2011). It is believed that these proteins play regulatory roles in the nucleation of hydroxyapatite onto dentin matrix collagen and in the subsequent growth of the hydroxyapatite crystals (Linde 1989, Suzuki et al. 2009, 2012). DSPP also plays a vital role in the formation and maintenance of a healthy periodontium (Gibson et al. 2013). The primary function of dentin phosphoprotein in odontoblasts is the extracellular mineralization of dentin, except for biglycan and bone sialoprotein, it acts as the nucleator and regulator of crystal growth and orientation
(Boskey 2003). Interestingly dentin phosphoprotein, although in the past it was thought to be a dentin-specific protein, is also present in nonmineralizing tissues such as the salivary glands or kidney, where it may participate in calcium transport (Alvares et al. 2013). It is assumed that dentin sialoprotein is modified by carbohydrates and this leads to unusual behaviour on SDS-PAGE (Qin et al. 2003). Some of the above mentioned proteins together with other proteins (e.g. matrix extracellular phosphoglycoprotein, dentin matrix acidic phospoprotein-1) associated with tooth tissue mineralization were substantially reviewed in a recent study (McKee et al. 2013).

Sialic acid-rich proteins are another group of non-collagenous protein present in dentin. Besides dentin sialoprotein, this category includes osteopontin, osteonectin, osteocalcin, bone sialoprotein, bone acidic glycoprotein, dentin matrix protein I, and integrin binding sialoprotein (Qin et al. 2001). These sialic acid-rich proteins share some common features, such as the presence of relatively large amounts of sialic acid, and phosphate groups. These proteins also play an important role in the highly sophisticated process of dentin mineralization (Suzuki et al. 2009).

Dentin matrix protein $I$ is a multifunctional acidic protein involved not only in the proper biomineralization of dentin and bones, but also in phosphate homeostasis and the differentiation of odontoblasts and osteoblasts (Beniash et al. 2011, Suzuki et al. 2012). Dentin matrix protein I is a highly phosphorylated protein, it contains a large number of phosphorylated serines. In the presence of calcium it undergoes self-assembly into filaments. Dentin matrix protein I specifically binds to the $\mathrm{N}$-telopeptide sequence of collagen and has been shown to affect collagen fibrogenesis. Periostin (Ma et al. 2011), osteocalcin, and osteonectin (Papagerakis et al. 2002) also have distinct roles in the dentin mineralization process.

Furthermore, a number of proteoglycans, belonging to the family of small leucine-rich proteoglycans, have been identified in predentin and dentin (Embery et al. 2001). Members of this family, biglycan and decorin, bind to collagen fibrils and hydroxyapatite crystals (Haruyama et al. 2009). Lumican, fibromodulin and osteoadherin are also involved in odontogenesis processes (Petersson et al. 2003).

To date, two complex proteomic studies investigating human dentin proteins have been done, where one-dimensional sodium dodecyl sulfate 
polyacrylamide gel electrophoresis (SDS-PAGE) was used, followed by tandem mass spectrometry (MS/MS) identification of the proteins (Park et al. 2009, Chun et al. 2011). Using SDS-PAGE, in total 233 proteins were found in three teeth in the older study. Similarly, 147 ethylenediaminetetraacetic acid (EDTA)-soluble tooth proteins were identified in the more recent study.

More recently, the proteins in human dentin have been comprehensively analyzed (Jágr et al. 2012). Five healthy permanent human molars from six adults were denaturated by guanidine and then demineralized by EDTA. The extracted proteins were identified by nLC-MS/MS. In total 289 proteins were identified with high confidence, 90 of which had not been previously detected in human dentin. Interestingly, some of these novel proteins had been identified in other classes of human calcified tissues (bone and cartilage).

The proteins identified in dentin have a variety of functions, including calcium ion binding, forming the cytoskeleton, cytoskeletal protein binding, forming the extracellular matrix, immune response, transport, and many other functions. A significant proportion of the proteins found in dentin (ca 10\%) had a biological function in immune response (Jágr et al. 2012). These proteins can play an important role in the prevention of dental caries.

\section{Proteomics of dental cementum}

Dental cementum is a thin layer and orofacial bone-like tissue covering the tooth root and surrounded by periodontal ligament, which contains Sharpey's fibers embedded in the cementum on one side and the alveolar bone on the other side to attach and suspend the tooth inside the alveolar socket of the alveolar bone (Bosshardt and Selvig 1997). Dental cementum is produced by cementoblasts, a common progenitor cell population in the ectomesenchymal dental follicle, which is also thought to be a subpopulation of merely positional osteoblasts (Bosshardt 2005). The process of cementogenesis remains poorly understood, although some key developmental processes have been studied via knock-out mice (Foster et al. 2011).

Dental cementum is often described as a bonelike tissue with many similarities in its morphology and matrix composition to alveolar bone, but these two mineralized tissues differ in some important respects. With respect to the proteomic approach, it has been hypothesized that the dental cementum matrix contains specific proteins responsible for its unique character.

Collagen type $\mathrm{I}$ is the primary extracellular matrix component of dental cementum. The remaining organic matrix is composed of various amounts of noncollagenous proteins. These include proteoglycans (e.g. versican, decorin, and biglycan), glycoproteins (e.g. osteonectin and arginine-glycine-aspartic acid integrinbinding proteins), and many other proteins (e.g. matrix gla protein, protein $\mathrm{S}$, and osteocalcin). All these proteins participate together in the regulation of cell metabolism, matrix deposition and mineralization, and thus may contribute to determining the structure and biomechanical properties of the tissue (Nanci 1999).

In a recent study, the proteome of dental cementum was comprehensively analyzed by LC-MS/MS and compared with the proteome of alveolar bone. A total of 213 proteins were identified in dental cementum, moreover some of them (83) were exclusive to the dental cementum matrix and were not observed in alveolar bone (Salmon et al. 2013). The authors also identified a potential biomarker for dental cementum, superoxide dismutase 3 , which is found in cementum and cementumassociated cells. This finding can help to better differentiate dental cementum and alveolar bone, which is necessary for the development of more efficient and predictable reconstructive therapies in periodontal diseases.

\section{Proteomics of tooth pulp}

Dental pulp is the uncalcified tissue located within the dental pulp cavity, surrounded by the hard dental tissues. This tissue supports the dentin and maintains many natural tooth functions: nourishment, sensory functions, immune defense reactions and demonstrates strong regenerative potential (Jontell et al. 1998). The dental pulp contains connective tissue, neural fibers, mesenchymal cells, blood vessels, and lymphatics. Blood vessels and nerve bundles enter the pulp through the apical foramen to provide nutrition and sensation for responding to external stimuli (Liu et al. 2006).

The dental pulp has the ability to form calcified tissue in response to various external influences such as dental caries, trauma and retransplantation of the tooth (Robertson et al. 1997, Ohshima et al. 2001, Ikeda-Isogai et al. 2012). It has been reported that dental pulp itself forms calcified tissue when transplanted subcutaneously (Yamazoe et al. 2002). In response to dental pulp injury, an early sprouting of nerve endings within the affected 
location was observed in human teeth (Sakurai et al. 1999). Accordingly, it has been demonstrated that denervated teeth have compromised dentin repair responses and show diminished dental pulp survival after injury (Byers and Taylor 1993). The aging of human adult teeth brings a progressive obliteration of dentinal tubules and/or a reduction of the terminal afferents of the dental pulp leading to a reduction in subjective ratings of pain intensity and thermal sensitivity (Ikeda and Suda 2003).

The immune system of dental pulp is comprised of dendritic cells, macrophages, lymphocytes, endothelial cells, and various epithelial and mesenchymal cells. They are a constituents of the dentin/pulp complex in which the immune system plays a pivotal role. Although they are not able to identify foreign antigens (when the integrity of enamel or dentin barrier is breached), they provide necessary signals to activate T-lymphocytes which in turn orchestrate other immunocompetent cells to mount the local immune defense of the dental pulp (Jontell et al. 1998).

In the last decade, dental pulp stem cells have become a promising tool for repairing the pulp-dentin complex (Pramila and Muthu 2012), and tooth regeneration via tissue engineering strategies using stem cells and stem cell/scaffold constructs (Zivkovic et al. 2010). These cells can differentiate into various tissues such as chondrocytes, odontoblasts, adipocytes, neural cells, and osteoblasts (Iohara et al. 2006). It was demonstrated that rat dental pulp stem cells from a fractured incisal portion of tooth crowns differentiate to odontogenic cells and thus have a regenerative capability (Shima et al. 2013). It is possible that all stem cells obtained from dental pulp are pluripotent (Pääkkönen and Tjäderhane 2010). They are capable of forming mineralized tissue, and they can also interact with various biomaterials (Wang et al. 2011).

There are two main teeth stem cell candidates suitable for dentin regeneration - dental pulp stem cells, and stem cells from exfoliated deciduous teeth (Alsanea et al. 2011). The development and characterization of the tooth slice/scaffold model of dental pulp tissue engineering was reviewed in 2011 (Sakai et al. 2011). The most commonly used transcriptomic and proteomic techniques and their use in dental pulp biology research were also recently described (Pääkkönen et al. 2010).

Only a few complex studies have described the proteome of human dental pulp to date (Pääkkönen et al. 2005, Wei et al. 2008). The first complex proteomic study investigating human dental pulp proteins was done in 2005 (Pääkkönen et al. 2005). Two-dimensional gel electrophoresis followed by MS/MS identification of the proteins was used, and in total 96 proteins were found. This study also compared the 2-DE gels of the pooled healthy and carious samples, but none of the 400 detectable protein spots were reproducibly changed. The cDNA microarray revealed several differentially expressed genes in carious tissues, but none of them were found in the 96 detected proteins. A comparison of the pulp tissues of healthy and mildly carious teeth revealed only slight expression changes, probably because the pulp of the carious teeth contained a high amount of healthy tissue (Pääkkönen et al. 2005).

The second proteomic study used difference gel electrophoresis to create a proteome reference map during the odontoblast-like differentiation of dental pulp cells in vitro. In total 23 proteins related to early odontogenetic differenciation were identified by MS. The expression of four identified proteins was confirmed by Western blotting (Wei et al. 2008).

Human pulp fibroblasts and odontoblast-like cells were shown to express desmoplakin and junction plakoglobin, intercellular junction proteins that tightly link adjacent cells (Sawa et al. 2005).

The immune defense role of dental pulp could be very important against dental carries. Elevated levels of the antimicrobial proteins S100A8, S100A9, and S100A13 were detected in the pulp of carious teeth (McLachlan et al. 2004). McLachlan et al. characterized pulpal tissue with carious lesions and performed semiquantitative PCR for selected genes, and confirmed the upregulation of two immune response proteins: alpha1 -acid glycoprotein 1 (orosomucoid 1) and interleukin 11 (McLachlan et al. 2005).

Small leucine-rich proteoglycans were found in dental pulp such as biglycan, lumican, and mimecan. The rigid, spatially oriented glycosaminoglycan chains on biglycan are known to bind calcium and may play direct roles in initialising mineralisation (Sandanayake et al. 2011).

Proteomic analyses of the osteogenic differentiation of dental follicle precursor cells were analyzed by 2-DE followed by MS, and in total 94 unique proteins were found to be regulated differently upon osteogenic differentiation compared to the control. Down-regulated proteins (for example cofilin 1, dextrin), and up-regulated proteins (actin cytoplasmic 1, protein disulfide isomerase) were identified (Morsczeck et al. 
2009).

A recent study (Mrozik et al. 2010) used similar proteomic techniques (2-DE, MS/MS) to compare the proteomes of mesenchymal stem-cell-like populations derived from bovine: i) bone marrow, ii) periodontal ligament, and iii) dental pulp. They showed the upregulation of five proteins in dental pulp compared to two other kinds of stem cells. Nine proteins of dental pulp stem cells were found to be upregulated compared to periodontal ligament stem cells: triosephosphate isomerase, alpha-enolase, collapsin response mediator protein, peroxiredoxin-2, vigilin, fascin homolog 1, fascin, transaldolase, cofilin 1. A comparison of dental pulp stem cells with bone marrow stem cells revealed the following upregulated proteins: chloride intracellular channel protein 1 , heat shock $70 \mathrm{kDa}$ protein, stress-70 protein, L-lactate dehydrogenase $\mathrm{B}$ chain, Rab GDP dissociation inhibitor beta, alpha-enolase, ubiquitin carboxyl-terminal hydrolase isozyme L1, collapsin response mediator protein, F-actin capping protein, eucariotic translation iniciation factor 3, C-1tetrahydrofolatesynthase, protein disulfide-isomerase A3, seril t-RNAsynthetase and gelsolin.

The EDTA extract from calcified tooth parts significantly enhanced dental pulp stem cell odontoblast differentiation and mineralization in vitro, but it only had a partial effect on bone marrow stem cells or adipose tissue stem cells (Chun et al. 2011). These findings are strong evidence of the importance of specific interactions inside the dental-pulp complex.

Vimentin was proposed to act as a quality standard for pulp regeneration and pulp cell function in a study of pulp stem/progenitor cells (Murakami et al. 2012). Asporin is probably involved in the regulation of the initial calcium deposition in the predentin layer, and plays an important role in predentin mineralization, because its expression is high in the early phase and then it decreases during the late phase of the odontogenic differentiation of human adult pulp stem cells (Lee et al. 2011b).

The results of Lee et al. suggest that a preamelobast-conditioned medium (from mouse apical bud cells) induces the odontogenic differentiation of human dental pulp stem cells and promotes dentin formation in vivo and in vitro (Lee et al. 2011c). In total 23 proteins were identified in this preameloblastconditioned medium.

Identifying the bioactive proteins present, especially in the pulp, has enabled their potential involvement in regenerative and other tissue responses to be better understood (Smith et al. 2012). These proteins could potentially offer paths to novel clinical therapies.

\section{Proteomics of saliva and pellicle layer}

Whole saliva is a complex mixture, including the secretions of the major and minor salivary glands, epithelial cells, serum, crevicular fluid, bacteria and food debris. Many proteins in saliva are differentially expressed in secretions, depending on the salivary gland that secrets them. The total protein concentration in the secretion from any one gland varies considerably, depending on factors such as the duration of stimulations, nature of the stimulus, flow rate and circadian rhythm (Siqueira and Dawes 2011).

The predominant proteins and peptides in whole saliva include amylase, carbonic anhydrase, mucins, cystatins, proline-rich proteins, histatins and statherin (Amado et al. 2005). Defense proteins (i.e. antibodies, cystatins, mucins) form an important part of the saliva proteome (Fábián et al. 2012).

The proteomic analysis of saliva has shown that the salivary proteome consists of more than three thousand distinct proteins (Amado et al. 2012). The comprehensive catalogue of saliva proteins (totalling 2290) from the experimental work of many laboratories was compiled and compared with 2698 plasma proteins. Approximately $27 \%$ of the whole-saliva proteins were found in plasma (Loo et al. 2010). A total sum of 1939 salivary proteins was detected in another study (Yan et al. 2009).

Siqueira et al. analyzed a global proteome of the human pellicle in 2007, and in total 130 proteins were identified (Siqueira et al. 2007). These proteins were categorized into three groups based upon their possible role in the acquired enamel pellicle (together adding up to $61 \%$ of all the identified proteins). The first group consisted of proteins that have the ability to bind calcium ions $(18 \%)$, the second group (15\%) were proteins that bind phosphate ions, and the third group (28\%) consisted of proteins that had been reported to have interactions with the other proteins (Siqueira et al. 2007).

Lee et al. quantified 50 proteins in the pellicle layer and demonstrated that there are significant qualitative and quantitative proteome changes during the acquired enamel pellicle formation, which could have a large impact on the development of oral biofilms (Lee et al. 2013b). 
The non-invasive and simple nature of saliva collection enables the repetition and multiple collection of this fluid that can potentially aid in early diagnosis, monitoring disease progression, or treatment responses. Disease-related salivary biomarkers were defined and summarized (i.e. for hereditary and autoimmune diseases, malignancies, dental caries, periodontal diseases) and identified by various studies of saliva proteomics (Al-Tarawneh et al. 2011, Amado et al. 2012).

Some of the studies compared the protein saliva composition of people with carious teeth and people with no caries. In this way, a significantly higher level of lipids and proteins was observed in the caries-susceptible group (Tomita et al. 2008). In a project comparing two groups of old people with and without root caries and one group of young people without root caries, 14 protein markers were observed (Preza et al. 2009). Another study, focussing on enamel tooth caries, compared two groups of younger people, and detected 44 differences in the protein content of their saliva (Vitorino et al. 2006). This study also compared the proteins of the in vitro created pellicle, and also found significant differences in the proteomes of the studied groups (Vitorino et al. 2006). Finally, biomarker validation was very different in the two above studies, probably due to using different sources or detection techniques (Al-Tarawneh et al. 2011).

A gender difference in oral health has been widely documented throughout time and in various cultures - women's oral health has always declined more rapidly than men's since the origin of agriculture. Representative studies of gender differences in caries, tooth loss, and periodontal disease have also been reviewed (Lukacs 2011).

All these differences mentioned above could be caused by the different composition of the saliva proteome. Proteomic analysis of oral fluids revealed differences in protein expression according to gender and age (Fleissig et al. 2010, Qin et al. 2013). Fleissig et al. detected gender differences of six proteins with significantly higher expression in females, including b-2microglobulin (Fleissig et al. 2010). Seven lectins exhibited significant gender differences in children, adults and elderly people. Four lectins were upregulated in female saliva (WFA, STL, LEL, GNA) and three (PSA, PNA, NPA) in male saliva (Qin et al. 2013).

\section{Conclusion}

The proteomic research of human teeth is an emerging field of biological, medical and analytical research. It could have a high impact on the understanding of various diseases, not only on dental caries. In this context, studies of the influence of age, gender, diet regime, teeth cleaning etc. on the quality of teeth are proposed. However, it is necessary to describe the proteome of teeth, their parts, including the pellicle layer and saliva. Of course, this means not only describing the proteome but in the next step to understand their functions during the development and formation of teeth and during resistance against attacks such as caries. From all of these perspectives, it focusing on teeth appears to be an interesting way forward.

\section{Conflict of Interest}

There is no conflict of interest.

\section{Acknowledgements}

This work was supported by the Ministry of Health Departmental Program for Research and Development (NT14324-3/2013), and with institutional support RVO:67985823.

\section{References}

ALSANEA R, RAVINDRAN S, FAYAD MI, JOHNSON BR, WENCKUS CS, HAO J, GEORGE A: Biomimetic approach to perforation repair using dental pulp stem cells and dentin matrix protein 1. J Endod 37: 1092-1097, 2011.

AL-TARAWNEH SK, BORDER MB, DIBBLE CF, BENCHARIT S: Defining salivary biomarkers using mass spectrometry-based proteomics. Omics 15: 353-361, 2011.

ALVARES K, STERN PH, VEIS A: Dentin phosphoprotein binds annexin 2 and is involved in calcium transport in rat kidney ureteric bud cells. J Biol Chem 288: 13036-13045, 2013.

AMADO FM, VITORINO RM, DOMINGUES PM, LOBO MJ, DUARTE JA: Analysis of the human saliva proteome. Proteomics 2: 521-539, 2005. 
AMADO FM, FERREIRA RP, VITORINO RM: One decade of salivary proteomics: current approaches and outstanding challenges. Clin Biochem 46: 506-517, 2012.

BAR-ON B, WAGNER HD: Structural motifs and elastic properties of hierarchical biological tissues - a review. J Struct Biol 183: 149-164, 2013.

BARRON MJ, MCDONNELL ST, MACKIE I, DIXON MJ: Hereditary dentine disorders, dentinogenesis imperfecta and dentine dysplasia. Orphanet J Rare Dis 3: 31, 2008.

BENIASH E, DESHPANDE AS, FANG PA, LIEB NS, ZHANG XY, SFEIR CS: Possible role of DMP1 in dentin mineralization. J Struct Biol 174: 100-106, 2011.

BOSKEY A: Biomineralization: an overview. Connect Tissue Res 44: 5-9, 2003.

BOSSHARDT DD: Are cementoblasts a subpopulation of osteoblasts or a unique phenotype? J Dent Res 84: 390-406, 2005.

BOSSHARDT DD, SELVIG KA: Dental cementum: the dynamic tissue covering of the root. Periodontol 2000 13: 41-75, 1997.

BUTLER WT, BRUNN JC, QIN C: Dentin extracellular matrix (ECM) proteins: comparison to bone ECM and contribution to dynamics of dentinogenesis. Connect Tissue Res 44: 171-178, 2003.

BYERS MR, TAYLOR PE: Effect of sensory denervation on the response of rat molar pulp to exposure injury. $J$ Dent Res 72: 613-618, 1993.

CHUN SY, LEE HJ, CHOI YA, KIM KM, BAEK SH, PARK HS, KIM JY, AHN JM, CHO JY, CHO DW, SHIN HI, PARK EK: Analysis of the soluble human tooth proteome and its ability to induce dentin/tooth regeneration. Tissue Eng A 17: 181-191, 2011.

COUVE E, OSORIO R, SCHMACHTENBERG O: The amazing odontoblast: activity, autophagy, and aging. $J$ Dent Res 92: 765-772, 2013.

De COSTER PJ, CORNELISSEN M, DE PAEPE A, MARTENS LC, VRAL A: Abnormal dentin structure in two novel gene mutations [COL1A1; Arg134Cys] and [ADAMTS2; Trp795-to-ter] causing rare type I collagen disorders. Arch Oral Biol 52: 101-109, 2007.

DUSEVICH V, XU CQ, WANG Y, WALKER MP, GORSKI JP: Identification of a protein-containing enamel matrix layer which bridges with the dentine-enamel junction of adult human teeth. Arch Oral Biol 57: 1585-1594, 2012.

EMBERY G, HALL R, WADDINGTON R, SEPTIER D, GOLDBERG M: Proteoglycans in dentinogenesis. Crit Rev Oral Biol Med 12: 331-349, 2001.

FÁBIÁN TK, FEJÉRDY P, CSERMELY P: Salivary genomics, transcriptomics and proteomics: the emerging content of the oral ecosystem and their use in the early diagnosis of cancer and other diseases. Curr Genomics 9: 11-21, 2008.

FÁBIÁN TK, HERMANN P, BECK A, FEJÉRDY P, FÁBIÁN G: Salivary defense proteins: their network and role in innate and acquired oral immunity. Int J Mol Sci 13: 4295-4320, 2012.

FARAH RA, MONK BC, SWAIN MV, DRUMMOND BK: Protein content of molar-incisor hypomineralization enamel. J Dent 38: 591-596, 2010.

FLEISSIG Y, REICHENBERG E, REDLICH M, ZAKS B, DEUTSCH O, AFRAMIAN DJ, PALMON A: Comparative proteomic analysis of human oral fluids according to gender and age. Oral Dis 16: 831-838, 2010.

FOSTER BL, NAGATOMO KJ, BAMASHMOUS SO, TOMPKINS KA, FONG H, DUNN D, CHU EY, GUENTHER C, KINGSLEY DM, RUTHERFORD RB, SOMERMAN MJ: The progressive ankylosis protein regulates cementum apposition and extracellular matrix composition. Cells Tissues Organs 194: 382-405, 2011.

GARCÍA-GODOY F, HICKS MJ: Maintaining the integrity of the enamel surface. The role of dental biofilm, saliva and preventive agents in enamel demineralization and remineralization. J Am Dent Assoc 139: 25S-34S, 2008.

GIBSON MP, ZHU Q, LIU Q, D'SOUZA RN, FENG JQ, QIN C: Loss of dentin sialophosphoprotein leads to periodontal diseases in mice. J Periodontal Res 48: 221-227, 2013.

HANNIG C, HANNIG M, ATTIN T: Enzymes in the acquired enamel pellicle. Eur J Oral Sci 113: 2-13, 2005.

HART PS, HART TC: Disorders of human dentin. Cells Tissues Organs 186: 70-77, 2007. 
HARUYAMA N, SREENATH TL, SUZUKI S, YAO XM, WANG Y, HONEYCUTT C, IOZZO RV, YOUNG MF, KULKARNI AB: Genetic evidence for key roles of decorin and biglycan in dentin mineralization. Matrix Biol 28: 129-136, 2009.

HE LH, SWAIN MV: Understanding the mechanical behavior of human enamel from its structural and compositional characteristics. J Mech Behav Biomed Mater 1: 18-29, 2008.

HU JCC, YAMAKOSHI Y: Enamelin and autosomal-dominant amelogenesis imperfecta. Crit Rev Oral Biol Med 14: 387-398, 2003.

HU JCC, YAMAKOSHI Y, YAMAKOSHI F, KREBSBACH PH, SIMMER JP: Proteomics and genetics of dental enamel. Cells Tissues Organs 181: 219-231, 2005.

HU JCC, CHUN YHP, AL HAZZAZZI T, SIMMER JP: Enamel formation and amelogenesis imperfecta. Cells Tissues Organs 186: 78-85, 2007.

HUBBARD MJ, KON JC: Proteomic analysis of dental tissues. J Chromatogr B 771: 211-220, 2002.

IKEDA H, SUDA H: Sensory experiences in relation to pulpal nerve activation of human teeth in different age groups. Arch Oral Biol 48: 835-841, 2003.

IKEDA-ISOGAI M, OHTSUKA T, BABA K, NONAKA N, NAKAMURA M: Calcified tissue formation of subcutaneously transplanted mouse dental pulp. Acta Histochem 114: 55-61, 2012.

IOHARA K, ZHENG L, ITO M, TOMOKIYO A, MATSUSHITA K, NAKASHIMA M: Side population cells isolated from porcine dental pulp tissue with self-renewal and multipotency for dentinogenesis, chondrogenesis, adipogenesis, and neurogenesis. Stem Cells 24: 2493-2503, 2006.

JÁGR M, ECKHARDT A, PATARIDIS S, MIKŠÍK I: A comprehensive proteomics analysis of human dentin. Eur $J$ Oral Sci 120: 259-268, 2012.

JONTELL M, OKIJI T, DAHLGREN U, BERGENHOLTZ G: Immune defense mechanisms of the dental pulp. Crit Rev Oral Biol Med 9: 179-200, 1998.

LEE KE, KANG HY, YOO SH, LEE JC, HWANG YH, NAM KH, KIM JS, PARK JC, KIM JW: Novel dentin phosphoprotein frameshift mutations in dentinogenesis imperfecta type II. Clin Genet 79: 378-384, $2011 \mathrm{a}$.

LEE EH, PARK HJ, JEONG JH, KIM YJ, CHA DW, KWON DK, LEE SH, CHO JY: The role of asporin in mineralization of human dental pulp stem cells. J Cell Physiol 226: 1676-1682, 2011 b.

LEE JH, LEE DS, CHOUNG HW, SHON WJ, SEO BM, LEE EH, CHO JY, PARK JC: Odontogenic differentiation of human dental pulp stem cells induced by preameloblast-derived factors. Biomaterials 32: 9696-9706, 2011c.

LEE SK, LEE KE, SONG SJ, HYUN HK, LEE SH, KIM JW: A DSPP mutation causing dentinogenesis imperfecta and characterization of the mutational effect. Biomed Res Int: Article number: 948181, 2013a.

LEE YH ZIMMERMAN JN, CUSTODIO W, XIAO Y, BASIRI T, HATIBOVIC-KOFMAN S, SIQUEIRA L: Proteomic evaluation of acquired enamel pellicle during in vivo formation. Plos one 8: e67919, 2013b.

LINDE A: Dentin matrix proteins, Composition and possible functions in calcification. Anat Rec 224: 154-166, 1989.

LIU H, GRONTHOS S, SHI S: Dental pulp stem cells. Method Enzymol 419: 99-113, 2006.

LOO JA, YAN W, RAMACHANDRAN P, WONG DT: Comparative human salivary and plasma proteomes. $J$ Dent Res 89: 1016-1023, 2010.

LU Y, PAPAGERAKIS P, YAMAKOSHI Y, HU JCC, BARTLETT JD, SIMMER JP: Functions of KLK4 and MMP-20 in dental enamel formation. Biol Chem 389: 695-700, 2008.

LUKACS JR: Sex differences in dental caries experience: clinical evidence, complex etiology. Clin Oral Invest 15: 649-656, 2011.

MA D, ZHANG R, SUN Y, RIOS HF, HARUYAMA N, HAN X, KULKARNI AB, QIN C, FENG JQ: A novel role of periostin in postnatal tooth formation and mineralization. J Biol Chem 286: 4302-4309, 2011.

MARSHALL GW, MARSHALL SJ, KINNEY JH, BALOOCH M: The dentin substrate, structure and properties related to bonding. J Dent 25: 441-458, 1997.

MAZZONI A, PASHLEY DH, TAY FR, GOBBI P, ORSINI G, RUGGERI A, CARRILHO M, TJÄDERHANE L, DI LENARDA R, BRESCHI L: Immunohistochemical identification of MMP-2 and MMP-9 in human dentin, correlative FEI-SEM/TEM analysis. $J$ Biomed Mater Res A 88: 697-703, 2009. 
MCKEE MD, HOAC B, ADDISON WN, BARROS NMT, MILLÁN JL, CHAUSSAIN C: Extracellular matrix mineralization in periodontal tissues: noncollagenous matrix proteins, enzymes, and relationship to hypophosphatasia and X-linked hypophosphatemia. Periodontology 2000 63: 102-122, 2013.

MCLACHLAN JL, SLOAN AJ, SMITH AJ, LANDINI G, COOPER PR: S100 and cytokine expression in caries. Infect Immun 72: 4102-4108, 2004.

MCLACHLAN JL, SMITH AJ, BUJALSKA IJ, COOPER PR: Gene expression profiling of pulpal tissue reveals the molecular complexity of dental caries. Biochim Biophys Acta 1741: 271-281, 2005.

MORSCZECK C, PETERSEN J, VOLLNER F, DRIEMEL O, REICHERT T, BECK HC: Proteomic analysis of osteogenic differentiation of dental follicle precursor cells. Electrophoresis 30: 1175-1184, 2009.

MROZIK KM, ZILM PS, BAGLEY CJ, HACK S, HOFFMANN P, GRONTHOS S, BARTOLD PM: Proteomic characterization of mesenchymal stem cell-like populations derived from ovine periodontal ligament, dental pulp, and bone marrow: analysis of differentially expressed proteins. Stem Cells Dev 19: 1485-1499, 2010.

MURAKAMI M, IMABAYASHI K, WATANABE A, TAKEUCHI N, ISCHIZAKA R, IOHARA K, YAMAMOTO T, NAKAMURA H, NAKASHIMA M: Identification of novel function of vimentin for quality standard for regenerated pulp tissue. J Endod 38: 920-926, 2012.

MYLLYHARJU J, KIVIRIKKO KK: Collagens, modifying enzymes and their mutations in humans, flies and worms. Trends Genet 20: 33-43, 2004.

NANCI A: Content and distribution of noncollagenous matrix proteins in bone and cementum: relationship to speed of formation and collagen packing density. $J$ Struct Biol 126: 256-269, 1999.

OHSHIMA H, NAKAKURA-OHSHIMA K, YAMAMOTO H, MAEDA T: Alteration in the expression of heat shock protein (Hsp) 25-immunoreactivity in the dental pulp of rat molars following tooth replantation. Arch Histol Cytol 64: 425-437, 2001.

PÄÄKKÖNEN V, OHLMEIER S, BERGMANN U, LARMAS M, SALO T, TJÄDERHANE L: Analysis of gene and protein expression in healthy and carious tooth pulp with cDNA microarray and two-dimensional gel electrophoresis. Eur J Oral Sci 113: 369-379, 2005.

PÄÄKKÖNEN V, TJÄDERHANE L: High-throughput gene and protein expression analysis in pulp biologic research: review. J Endod 36: 179-189, 2010.

PAINE ML, SNEAD ML: Tooth developmental biology: disruptions to enamel-matrix assembly and its impact on biomineralization. Orthod Craniofacial Res 8: 239-251, 2005.

PAINE ML, LUO W, WANG HJ, BRINGAS P, NGAN AYW, MIKLUS VG, ZHU DH, MACDOUGALL M, WHITE SN, SNEAD ML: Dentin sialoprotein and dentin phosphoprotein overexpression during amelogenesis. $J$ Biol Chem 280: 31991-31998, 2005.

PAPAGERAKIS P, BERDAL A, MESBAH M, PEUCHMAUR M, MALAVAL L, NYDEGGER J, SIMMER J, MACDOUGALL M: Investigation of osteocalcin, osteonectin, and dentin sialophosphoprotein in developing human teeth. Bone 30: 377-385, 2002.

PARK ES, CHO HS, KWON TG, JANG SN, LEE SH, AN CH, SHIN HI, KIM JY, CHO JY: Proteomics analysis of human dentin reveals distinct protein expression profiles. J Proteome Res 8: 1338-1346, 2009.

PETERSSON U, HULTENBY K, WENDEL M: Identification, distribution and expression of osteoadherin during tooth formation. Eur J Oral Sci 111: 128-136, 2003.

PORTO IM, LINE SRP, LAURE HJ, GERLACH RF: Comparison of three methods for enamel protein extraction in different developmental phases of rat lower incisors. Eur J Oral Sci 114: 272-275, 2006.

PRAMILA R, MUTHU M: Regeneration potential of pulp-dentin complex: systematic review. $J$ Conserv Dent 15: 97-103, 2012.

PREZA D, THIEDE B, OLSEN I, GRINDE B: The proteome of the human parotid gland secretion in elderly with and without root caries. Acta Odontol Scand 67: 161-169, 2009.

QIN C, BRUNN JC, JONES J, GEORGE A, RAMACHANDRAN A, GORSKI JP, BUTLER WTA: A comparative study of sialic acid-rich proteins in rat bone and dentin. Eur J Oral Sci 109: 133-141, 2001.

QIN C, BRUNN JC, BABA O, WYGANT JN, MCINTYRE BW, BUTLER WT: Dentin sialoprotein isoforms, detection and characterization of a high molecular weight dentin sialoprotein. Eur J Oral Sci 111: 235-242, 2003. 
QIN Y, ZHONG Y, ZHU M, DANG L, YU H, CHEN Z, CHEN W, WANG X, ZHANG H, LI Z: Age- and sexassociated differences in the glycopatterns of human salivary glycoproteins and their roles against influenza $A$ virus. J Proteome Res 12: 2742-2754, 2013.

RABILLOUD T, CHEVALLET M, LUCHE S, LELONG C: Two-dimensional gel electrophoresis in proteomics: past, present and future. J Proteomics 73: 2064-2077, 2010.

REZENDE TMB, LIMA SMF, PETRIZ BA, SILVA ON, FREIRE MS, FRANCO OL: Dentistry proteomics: from laboratory development to clinical practice. J Cell Physiol 228: 2271-2284, 2013.

ROBERTSON A, LUNDGREN T, ANDREASEN JO, DIETZ W, HOYER I, NOREN J: Pulp calcifications in traumatized primary incisors - a morphological and inductive analysis study. Eur J Oral Sci 105: 196-206, 1997.

SAKAI VT, CORDEIRO MM, DONG Z, ZHANG Z, ZEITLIN BD, NÖR JE: Tooth slice/scaffold model of dental pulp tissue engineering. Adv Dent Res 23: 325-332, 2011.

SAKURAI K, OKIJI T, SUDA H: Co-increase of nerve fibers and HLA-DR- and/or factor-XIIIa-expressing dendritic cells in dentinal caries-affected regions of the human dental pulp: an immunohistochemical study. $J$ Dent Res 78: 1596-1608, 1999.

SALMON CR, TOMAZELA DM, RUIZ KGS, FOSTER BL, LEME AFP, SALLUM EA, SOMERMAN MJ, NOCITI FH: Proteomic analysis of human dental cementum and alveolar bone. J Proteomics 91: 544-555, 2013.

SANDANAYAKE NS, SINCLAIR J, ANDREOLA F, CHAPMAN MH, XUE A, WEBSTER GJ, CLARKSON A, GILL A, NORTON ID, SMITH RC, TIMMS JF, PEREIRA SP: A combination of serum leucine-rich alpha-2glycoprotein 1, CA 19-9 and interleukin-6 differentiate biliary tract cancer from benign biliary structures. Brit J Cancer 105: 1370-1378, 2011.

SAWA Y, KUROSHIMA S, YAMAOKA Y, YOSHIDA S: Intracellular distribution of desmoplakin in human odontoblasts. J Histochem Cytochem 53: 1099-1108, 2005.

SHAW WJ, CAMPBELL AA, PAINE ML, SNEAD ML: The C-terminus of the amelogenin, LRAP, is orientated next to the hydroxyapatite surface. J Biol Chem 279: 40263-40266, 2004.

SHIMA H, MATSUZAKA K, KOKUBU E, INOUE T: Regenerative capability of dental pulp cells after crown fracture. Dent Traumatol 29: 29-33, 2013.

SIQUEIRA WL, ZHANG W, HELMERHORST EJ, GYGI SP, OPPENHEIM FG: Identification of protein components in in vivo human acquired enamel pellicle using LC-ESI-MS/MS. J Proteom Res 6: 2152-2160, 2007.

SIQUEIRA WL, DAWES C: The salivary proteome: challenges and perspectives. Proteom Clin Appl 5: 575-579, 2011.

SMITH AJ, SCHEVEN BA, TAKAHASHI Y, FERRACANE JL, SHELTON RM, COOPER PR: Dentine as a bioactive extracellular matrix. Arch Oral Biol 57: 109-121, 2012.

SUZUKI S, SREENATH T, HARUYAMA N, HONEYCUTT C, TERSE A, CHO A, KOHLER T, MÜLLER R, GOLDBERG M, KULKARNI AB: Dentin sialoprotein and dentin phosphoprotein have distinct roles in dentin mineralization. Matrix Biol 28: 221-229, 2009.

SUZUKI S, HARUYAMA N, NISHIMURA F, KULKARNI AB: Dentin sialophosphoprotein and dentin matrix protein-1: two highly phosphorylated proteins in mineralized tissues. Arch Oral Biol 57: 1165-1175, 2012.

TOMITA YN, MIYAKE N, YAMANAKA S: Lipids in human parotid saliva with regard to caries experience. $J$ Oleo Sci 57: 115-121, 2008.

TSUCHIYA S, SIMMER JP, HU JCC, RICHARDSON AS, YAMAKOSHI F, YAMAKOSHI Y: Astacin proteases cleave dentin sialophosphoprotein (Dspp) to generate dentin phosphoprotein (Dpp). $J$ Bone Miner Res 26: 220-228, 2011.

VITORINO R, GUEDES S, FERREIRA R, LOBO MJC, DUARTE J, FERRER-CORREIA AJ, TOMER KB, DOMINGUES PM, AMADO FML: Two-dimensional electrophoresis study of in vitro pellicle formation and dental caries susceptibility. Eur J Oral Sci 114: 147-153, 2006.

VITORINO RM, GUEDES S, MANADAS B, FERREIRA R, AMADO F: Toward a standardized saliva proteome analysis methodology. $J$ Proteomics 75: 5140-5165, 2012.

VYMĚTAL J, SLABÝ I, SPAHR A, VONDRÁŠEK J, LYNGSTADAAS SP: Bioinformatic analysis and molecular modelling of human ameloblastin suggest a two-domain intrinsically unstructured calcium-binding protein. Eur J Oral Sci 116: 124-134, 2008. 
WALD T, BEDNÁROVÁ L, OSIČKA R, PACHL P, ŠULC M, LYNGSTADAAS SP, SLABÝ I, VONDRÁŠEK J: Biophysical characterization of recombinant human ameloblastin. Eur J Oral Sci 119: 261-269, 2011.

WANG J, MA H, JIN X, HU J, LIU XH, NI LX, PA PX: The effect of scaffold architecture on odontogenic differentiation of human dental pulp stem cells. Biomaterials 32: 7822-7830, 2011.

WEI X, WU LP, LING JQ, LIU L, LIU S, LIU W, LI M, XIAO Y: Differentially expressed protein profile of human dental pulp cells in the early process of odontoblast-like differentiation in vitro. $J$ Endodont 34: 1077-1084, 2008.

YAMAKOSHI Y, HU JCC, IWATA T, KOBAYASHI K, FUKAE M, SIMMER JP: Dentin sialophosphoprotein is processed by MMP-2 and MMP-20 in vitro and in vivo. $J$ Biol Chem 281: 38235-38243, 2006.

YAMAZOE T, AOKI K, SIMOKAWA H, OHYA K, TAKAGI Y: Gene expression of bone matrix proteins in a calcified tissue appeared in subcutaneously transplanted rat dental pulp. J Med Dent Sci 49: 57-66, 2002.

YAN W, APWEILER R, BALGLEY BM, BOONTHEUNG P, BUNDY JL, CARGILE BJ, COLE S, FANG XP, GONZALEZ-BEGNE M, GRIFFIN T, HAGEN F, HU S, WOLINSKY LE, LEE CS, MALAMUD D, MELVIN JE, MENON R, MUELLER M, OIAO R, RHODUS NL, SEVINSKY JR, STATES D, STEPHENSON JL, THAN S, YATES JR, YU W, XIE H, XIE Y, OMENN GS, LOO JA, WONG DT: Systematic comparison of the human saliva and plasma proteomes. Proteom Clin Appl 3: 116-134, 2009.

ZENÓBIO MAF, TAVARES MSN, ZENÓBIO EG, SILVA TA: Elemental composition of dental biologic tissues: study by means of different analytical techniques. J Radioanal Nucl Chem 289: 161-166, 2011.

ZIVKOVIC P, PETROVIC V, NAJMAN S, STEFANOVIC V: Stem cell-based dental tissue engineering. ScientificWorldJournal 10: 901-916, 2010. 